\title{
Correction to: A novel approach for ports' container terminals' risk management based on formal safety assessment: FAHP-entropy measure-VIKOR model
}

\section{Saeed Khorram ${ }^{1}$ (D)}

Published online: 23 July 2020

(c) Springer Nature B.V. 2020

\section{Correction to: Natural Hazards} https://doi.org/10.1007/s11069-020-03976-z

The original article was published with a name spelling error. This correction stands to correct the original article noting the name behind the work to be credited as Saeed Khorram and not the prior. The original article has been corrected.

Publisher's Note Springer Nature remains neutral with regard to jurisdictional claims in published maps and institutional affiliations.

The original article can be found online at https://doi.org/10.1007/s11069-020-03976-z.

Saeed Khorram

saeedkhoram@gmail.com

1 Department of Civil Engineering, Marvdasht Branch, Islamic Azad University, Marvdasht, Iran 